\title{
Kebijakan Pendidikan Di Era New Normal
}

\author{
A.Irawan Rafsanjani \\ Mahasiswa Pendidikan IPS,FKIP Universitas Lambung Mangkurat \\ zaniahmad14@gmail.com
}

\begin{abstract}
ABSTRAK
Pendidikan saat ini memang menjadi dasar dari kemajuan pembangunan generasi bangsa. Peserta didik sebagai generasi emas penerus bangsa dipersiapkan untuk masa depan. Tentu tenaga pendidik merupakan kunci utama untuk menghasilkan generasi emas Indonesia yang dicanangkan akan tercapai tahun 2045 generasi yang bermutu dan berkualitas. Negara kita saat ini menghadapi wabah pandemi COVID-19 sehingga dengan demikian maka pemerintah menerapkan kebijakan pembelajaran secara online atau daring dimana peserta didik diharuskan belajar di rumah saja untuk menghindari terpaparnya COVID-19. Tentunya banyak kendala dalam pelaksanaan pembelajaran online atau daring ini, tetapi kegiatan pembelajaran kepada peserta didik harus tetap dilaksanakan ditengah kebijakan pemerintah di era new normal saat ini .Saat ini pemerintah kita sedang menerapkan kebijakan new normal tak terkecuali kenormalan baru pada sektor pendidikan. Pada kebijakan new normal saat ini kita sebagai masyarakat diharuskan untuk hidup secara berdampingan dengan pandemi COVID-19 tetapi tetap dengan memperhatikan segala aspek protokol kesehatan.Tujuan dalam tulisan ini untuk menjadikan pertimbangan guru atau tenaga pendidik dalam merencanakan strategi pembelajaran dan dalam menerapkan model pembelajaran jarak jauh atau online ini jadi diharapkan peserta didik akan mendapatkan pendidikan yang bermutu dan berkualitas. Untuk penerapannya maka diperlukan pembelajaran yang bervariasi dan inovatif supaya peserta didik tetap bergairah mengikuti pembelajaran walaupun pembelajaran dilaksanakan secara secara jarak jauh atau online. Pembelajaran online atau daring ini dapat dilakukan secara virtual, berkelompok sebagai wadah berdiskusi, pemberian materi kepada peserta didik dalam bentuk video, rekaman, powerpoint, modul, lembar belajar, permainan dengan game quizizz dan penilaian secara online atau daring juga bisa dilakukan dalam strategi pembelajaran online atau daring ini. Kelebihan pembelajaran online atau daring ini juga bisa menjadikan peserta didik akan lebih efektif dalam belajar karena pembelajaran tidak lelah, menyenangkan, pengalaman baru dan kelemahan pembelajaran online atau daring ini dari koneksi internet yang kurang baik, terkadang peserta didik juga kurang paham dengan materi, peserta didik merasa bosan, peserta didik tidak bisa berdiskusi dengan teman seleluasa seperti biasanya. Banyak peneliti dan praktisi telah mengakui bahwa elearning sebagai media pengajaran prospektif di masa depan menghadapi kesulitan dan tantangan untuk diterapkan dengan sukses (Abbas, E. W., \& Rajiani, I. (2019).Berdasarkan dari masalah tersebut maka kebijakan pembelajaran online atau daring haruslah menarik dan bervariasi agar memberikan manfaat bagi generasi emas dalam pembelajaran.
\end{abstract}

Kata kunci: pembelajaran, online atau daring ,new normal, generasi emas, COVID-19 


\section{PENDAHULUAN}

Pendidikan merupakan dasar elemen yang sangat penting untuk menyiapkan generasi emas bangsa dalam menghadapi era globalisasi yang sangat cepat ini,tentunya akan jadi tantangan yang cukup berat jika tidak diimbangi dengan persiapan sumber daya manusia yang memiliki daya saing tinggi secara global,untuk itulah perlunya menyiapkan sumber daya manusia yang berkualitas untuk generasi emas sebagai penerus kemajuan bangsa. Pembelajaran yang dilakukan tenaga pendidik dan peserta didik merupakan bekal bagi peserta didik untuk mendapatkan bekal yang terbaik guna untuk ketercapaian pendidikan dan pembelajaran yang bermakna. Tenaga pendidik memegang peranan kunci utama keberhasilan untuk dapat menghasilkan generasi emas Indonesia tahun 2045 yang bermutu dan berkualitas seperti yang telah dicanangkan. Oleh karena itu tenaga pendidik harus kompeten atau haruslah mempunyai kemampuan dalam mendesain dan merencanakan pembelajaran yang bermakna dan bermanfaat untuk perkembangan pengetahuan peserta didik.

Negara kita saat ini sedang menghadapi pandemi virus COVID-19 ini dan juga saat ini pemerintah menerapkan kebijakan new normal yang implikasinya berpengaruh terhadap sektor pendidikan sehingga peserta didik diminta untuk belajar di rumah demi menghindari terpaparnya COVID -19. Tenaga pendidik dan peserta didik diharuskan melakukan pembelajaran secara online atau daring sehingga tidak ada tatap muka di kelas seperti biasanya. Tentu kejadian seperti ini menuntut peserta didik dan juga tenaga pendidik harus belajar dan melakukan pembelajaran secara online atau daring atau jarak jauh tetapi dengan ketercapaian dan tujuan pendidikan yang tetap berkualitas dan bermutu (Syaharuddin, S. (2020).

Proses pembelajaran dalam bidang pendidikan harus terus berlangsung meski disaat ini tengah terjadi pandemi COVID-19 tetapi kebijakan new normal dan kebijakan pemerintah terhadap pendidikan secara online atau daring tetap dilaksanakan agar generasi emas tidak ketinggalan pengetahuan dalam belajar dan tetap melakukan pembelajaran demi kemajuan generasi penerus sebagai tunas kemajuan bangsa di masa mendatang.

Oleh karenanya tenaga pendidik harus dapat membekali peserta didik mereka dengan pendidikan dan keterampilan yang kompeten dan kompleks artinya diharapkan harus mempunyai keterampilan berpikir kritis, konstruktif, runut dan juga berkarakter. Pada penerapan pembelajaran online atau daring ini maka komunikasi jarak jauh tidak lepas dengan penggunaan elektronik seperti telepon genggam, tablet, atau laptop dan juga koneksi internet yang dimanfaatkan sebagai bagian dari kegiatan pembelajaran. 


\section{HASIL PEMBAHASAN}

\section{Implementasi Pembelajaran Terhadap Kebijakan Pendidikan Di Era New Normal}

Di era pandemi COVID-19 ini tentunya tidak memungkinkan untuk menerapkan pembelajaran dilaksanakan secara face to face atau secara langsung mungkin setidaknya bisa dilakukan dengan jarak jauh atau virtual yaitu pembelajaran secara online dengan melakukan live e-learning melalui berbagai platform aplikasi yang tersedia seperti Zoom, Google Meet , Google Classroom yang merupakan media berbasis aplikasi yang dapat dioptimalkan untuk wadah pembelajaran (Syaharuddin, S. (2020).

Melalui media aplikasi elektronik tersebut tenaga pendidik juga dapat mentransfer pengetahuan dan keterampilan seperti biasanya saat melakukan pembelajaran secara face to face atau langsung.Dalam pembelajaran jarak jauh atau online ini juga tetap bisa membangun karakter peserta didik misalnya saja dapat dilihat dengan disiplin waktu dalam memulai dan mengakhiri pertemuan kelas daring atau online, disiplin waktu batas waktu upload tugas, kemandirian melalui tugas individu, kerjasama melalui tugas kelompok dan etika dalam berbicara atau menulis saat live elearning berlangsung antara peserta didik dengan tenaga pendidik.Peran tenaga pendidik tentu tidak tergantikan oleh mesin (teknologi) (Syaharuddin, S. (2020).

Tetapi kemampuan tenaga pendidik menyentuh pada aspek rasa, bahasa dan pembentuk karakter menjadikan kehadirannya selalu ditunggu oleh peserta didik, kapan dan dimanapun teknologi tentu diciptakan untuk memudahkan pekerjaan manusia, termasuk dalam proses belajar.Perpaduan kedua hal ini merupakan solusi yang tepat dalam belajar di era ini dan khususnya saat penerapan kebijakan new normal saat ini. Saat ini proses pembelajaran tergantung kepada peserta didik dalam memahami materi dalam lingkup kelas jarak jauh atau online ini. hal ini tentunya perlu sekali di perhatikan pemerintah dalam kebijakan dalam hal mengevaluasi pendidikan di masa new normal. Kurikulum pendidikan juga disesuaikan dengan pandemi sekarang ini. Bisa dimulai dengan protokol kesehatan dengan menerapkan tetap menjaga jarak agar tidak terlalu berdekatan.

Para tenaga pendidik dan peserta didik juga tentunya dengan diterapkannya protokol kesehatan tentu akan merasa sedikit tenang dan aman saat proses belajar mengajar dilaksanakan. Wali murid atau orang tua murid di rumah saya rasa juga akan setuju apabila pembelajaran sudah dilakukan secara face to face langsung dengan adanya penerapan 
protokol kesehatan dan juga orang tua atau wali murid tentunya tak terlalu khawatir ketika anaknya melakukan proses belajar mengajar di kelas seperti sekolah pada biasanya.

Pandemi COVID-19 ini semakin serius seiring semakin melonjaknya angka masyarakat Indonesia yang terpapar COVID-19 sekarang ini juga dunia internasional juga dipusingkan menghadapi permasalahan pandemi COVID-19 ini.Berdasarakan fakta dilapangan dengan banyaknya angka yang terus melonjak terpapar COVID-19 di Indonesia penulis menyimpulkan bawah nantinya pelaksanaan dalam sektor pendidikan akan tetap berjalan sampai akhir tahun 2020 ini,Tetapi saat melakukan proses belajar mengajar secara jarak jauh atau online ini tentunya juga terdapat permasalahan yang sudah di rasakan ketika proses pembelajaran. Mau tidak mau baik peserta didik ataupun tenaga pendidik menurut penulis harus dapat beradaptasi dengan pembelajaran jarak jauh atau online ini.

Artinya dengan kondisi keadaan pandemi COVID-19 ini kita memang diharuskan untuk tetap menjaga jarak dan juga lebih baik dirumah saja apabila tidak terlalu melakukan aktivitas penting diluar rumah, penulis juga sebagai mahasiswa menerapkan pembelajaran secara mandiri dan juga menikmati waktu bersama keluarga semaksimal mungkin di era pandemi COVID-19 saat ini.

Sudah seharusnya kita harus bersikap bijak terhadap situasi saat ini dengan melakukan hal-hal yang produktif, misalnya saja dengan ikit,seminar, lomba karya tulis dan lain sebagainya. Semoga saja pandemi COVID-19 ini segera berakhir di tanah air dan dunia Internasional sehingga sektor pendidikan akan pulih kembali normal seperti biasanya. Perencanaan persiapan pada sektor pendidikan juga mulai digalangkan seiring dengan kebijakan pendidikan di era new perencanaan persiapan dimulai dari kebijakan protokol kesehatan yang akan di terapkan sampai pandemi berakhir.

Artinya aktivitas tentu akan terasa berbeda sekali proses belajar dan mengajar yang dilakukan.Tetapi inilah salah satu cara supaya dunia pendidikan tidak terpuruk di saat situasi pandemi saat ini. Akhir pandemi COVID-19 ini juga belum memiliki kepastian kapan virus pandemi ini akan berakhir, Tentunya dengan kita menerapkan protokol kesehatan dengan pola hidup sehat, merupakan salah satu cara agar terhindar paparan virus COVID-19.

Dengan penerapan pola hidup sehat di kenormalan yang baru ini atau era new normal ini merupakan kunci kedisiplinan agar tetap menjaga pola hidup sehat yang baik. Upaya persiapan pada sektor pendidikan di era new normal ini sudah dilakukan dilaksanakan dengan cara memanfaatkan teknologi yang menunjang atau memungkinkan efektivitas pembelajaran.

Setidaknya proses belajar mengajar secara jarak jauh atau online ini setidaknya sudah digalangkan dalam rentang waktu empat bulan terakhir ini . Sudah pasti pembelajaran jarak 
jauh atau online ini telah mendapatkan reaksi dari berbagai pihak tak terkecuali dari orang tua atau wali dari peserta didik.

Orang tua atau wali dari peserta didik ini menurut penulis cukup beralasan memang saat orang tua atau wali peserta didik masih mengeluhkan akan kendala pembelajaran dan juga orang tua dan wali peserta didik juga banyak yang mempertanyakan efektivitas proses belajar mengajar secara jarak jauh atau online yang sedang digalangkan saat ini. Seperti yang di ketahui bahwa tercatat hingga sampai hari kasus penyebaran COVID-19 di Indonesia masih belum berhenti bahkan terus melonjak angkanya dan kebijakan pendidikan harus diperhatikan dan pertimbangkan oleh berbagai pihak tak terkecuali dinas pendidikan dan juga Kemendikbud. Apabila nantinya proses pembelajaran dibuka kembali seperti semula haruslah memenuhi syarat protokol kesehatan COVID-19 selama kegiatan pembelajaran berlangsung.

Tetapi wilayah-wilayah khususnya dari pedesaan dalam menerapkan pendidikan sangat membutuhkan sekali dukungan sarana fasilitas dalam menerapkan protokol kesehatan. Berdasarkan fakta di lapangan saat ini terdapat sekali banyak wilayah pendidikan di Indonesia yang saat ini belum memenuhi syarat dengan fasilitas standar protokol kesehatan COVID-19. Agar proses pembelajaran dapat berjalan dengan optimal. Seharusnya lembaga pendidikan dan pemerintah harus bekerja sama selama masa new normal di berlakukan.

\section{SIMPULAN}

Pihak pemangku kebijakan di sektor pendidikan haruslah ekstra keras dalam menjalankan dan menerapkan kebijakan ini khususnya Mendikbud dan tak terkecuali juga dinas pendidikan. Kebijakan apapun dalam sektor pendidikan yang nantinya diambil pasti perlu direncanakan dengan matang pastinya juga akan berimbas pada ketersediaan dana. Untuk itu, pihak pemangku pendidikan seperti dinas pendidikan wajib berkoordinasi secara matang dengan kepala sekolah dari semua sekolah yang ada disatu kabupaten misalnya saja berkoordinasi tentang perencanaan penyediaan sarana dan prasarana yang dibutuhkan selama masa pandemi di lingkungan sekolah untuk mendukung kebijakan new normal dalam pendidikan. Pihak sekolah sendiri wajib menyediakan standarisasi protokol kesehatan untuk peserta didik dan juga tenaga pendidik yang berada di lingkungan sekolah misalnya saja penyediaan masker dan hand sanitaizer bagi peserta didik yang dalam kategori kurang mampu (Syaharuddin, S. (2020).

Pihak sekolah juga wajib menyediakan tempat cuci tangan misalnya dengan membuatkan kran pada masing-masing kelas.Terkait dengan pelaksanaan kegiatan belajar mengajar di sekolah menurut penulis bisa dilakukan dengan cara dinas pendidikan dan pihak sekolah harus memberdayakan tenaga pendidik honorer untuk membantu pelaksanaannya. 
Hal ini dimaksudkan untuk memberikan kesempatan beristirahat yang cukup bagi guru atau tenaga pendidik dengan istirahat yang cukup tentunya sistem imun tubuh terjaga dengan baik dan apabila sistem imun tubuh maka akan membentuk anti bodi atau pertahanan diri yang bagus untuk melawan virus laju virus COVID-19.

\section{DAFTAR PUSTAKA}

ABBAS, E. W., Hidayat Putra, M. A., \& Noor Handy, M. R. (2019). Laporan Penelitian: PEMANFAATAN EKOWISATA SUNGAI MARTAPURA KOTA BANJARMASIN SEBAGAI SUMBER BELAJAR IPS. Subiyakto, B., \& Akmal, H. (2020). Profesi Keguruan.

Abbas, E. W. (Ed.). (2017). Membangun pendidikan. Fakultas Keguruan dan Ilmu Pendidikan, Universitas Lambung Mangkurat.Syaharuddin, S. (2020). PEMBELAJARAN MASA PANDEMI: DARI KONVENSIONAL KE DARING. PEMBELAJARAN MASA PANDEMI: DARI KONVENSIONAL KE DARING.

Abbas, E. W. (2018). Penguatan Pendidikan IPS Di Tengah Isu-Isu Global.

Hasanah, M., ABBAS, E. W., Subiyakto, B., Fikriah, N., \& Syahrin, M. A. (2017). Implementasi Pembelajaran IPS yang Berbasis Kearifan Lokal di SMPN 1 Gambut Kabupaten Banjar. Implementasi Pembelajaran IPS yang Berbasis Kearifan Lokal di SMPN 1 Gambut Kabupaten Banjar.

Mutiani, M., Abbas, E. W., Syaharuddin, S., \& Susanto, H. Membangun Komunitas Belajar Melalui Lesson Study Model Transcript Based Learning Analysis (TBLA) dalam Pembelajaran Sejarah. Historia: Jurnal Pendidik dan Peneliti Sejarah, 3(2), 113-122.

Mutiani, M. (2019). INTERNALISASI NILAI PENDIDIKAN MELALUI AKTIVITAS MASYARAKAT SEBAGAI SUMBER BELAJAR ILMU PENGETAHUAN SOSIAL. INTERNALISASI NILAI PENDIDIKAN MELALUI AKTIVITAS MASYARAKAT SEBAGAI SUMBER BELAJAR ILMU PENGETAHUAN SOSIAL.

Subiyakto, B., \& Abbas, E. W. (2020). Strategi Pembelajaran IPS: Konsep dan Aplikasi.Subiyakto, B., \& Abbas, E. W. (2020). Strategi Pembelajaran IPS: Konsep dan Aplikasi.

Susanto, H., \& Akmal, H. (2018). Efektivitas Penggunaan Aplikasi Pembelajaran Berbasis Mobile Smartphone Sebagai Media Pengenalan Sejarah Lokal Masa Revolusi Fisik Di Kalimantan Selatan Pada Siswa Sekolah Menengah Atas. HISTORIA: Jurnal Program Studi Pendidikan Sejarah, 6(2), 197-206.

Susanto, H., \& Akmal, H. (2019). Media Pembelajaran Sejarah Era Teknologi Informasi (Konsep Dasar, Prinsi Aplikatif, dan Perancangannya). 
Subiyakto, B., \& Mutiani, M. (2019). Internalisasi nilai pendidikan melalui aktivitas masyarakat sebagai sumber belajar ilmu pengetahuan sosial. Khazanah: Jurnal Studi Islam dan Humaniora, 17(1), 137-166.

Subiyakto, B. (2019). Media Pembelajaran Sejarah Era Teknologi Informasi.

Susanto, H. (2020). Profesi Keguruan.

Syaharuddin, S., \& Mutiani, M. (2020). STRATEGI PEMBELAJARAN IPS: Konsep dan Aplikasi.

Syaharuddin, S. (2020). Menimbang Peran Teknologi dan Guru dalam Pembelajaran di Era COVID-19. Menimbang Peran Teknologi dan Guru dalam Pembelajaran di Era COVID-19.

Syaharuddin, S., Rahman, A. M., \& Fitriyani, R. (2020). Utilization Of Social Community as Learning Resources On Social Studies. The Kalimantan Social Studies Journal, 1 (1), $18-24$.

Syaharuddin, S., Rahman, A. M., \& Fitriyani, R. (2019). Utilization Of Social Community as Learning Resources On Social Studies. The Kalimantan Social Studies Journal, 1(1), $18-24$. 